\title{
Millimole per Liter per Microgram per Meter Squared per Day
}

National Cancer Institute

\section{Source}

National Cancer Institute. Millimole per Liter per Microgram per Meter Squared per Day. NCI Thesaurus. Code C119422.

A unit of concentration equal to millimoles per liter, divided by micrograms per meter squared per day. 